13. Pharmencyclopedia (2010). https://www.pharmencyclopedia.com.ua/ article/1468/mikroorganizmi. [in Ukrainian].

14. Dickson, S.H. (1839). On dengue: its history, pathology, and treatment. https://archive.org/details/100887678. nlm.nih.gov

15. Fauquet, C.M., Mayo, M.A., Maniloff, J., Desselberger, U., Ball, L.A. (2005). Virus Taxonomy. Eighth Report of the International Committee on Taxonomy of Viruses. Copyright. Elsevier Inc. 1259 p.

16. Flewett, T.H., Bryden, A.S., Davies, H., Woode, G.N., Bridger, J.C., Derrick, J.M. (1974). Relation between viruses from acute gastroenteritis of children and newborn calves. The Lancet: journal. Elsevier. Vol. 2, No. 7872. P. 61-63. - doi:10.1016/ S0140-6736(74)91631-6. PMID 4137164

17. Harper, D. (2001). Etymology: dengue. Online Etymology Dictionary. Archive of the original by 2009-01-29. Cited 2008-10-05. https://web.archive.org/ web/20090129205429/http://www.etymonline.com/index.php?term=dengue

18. King, A.M.Q., Adam, M.J., Carstens, E.B., Lefkowitz, E.J. (eds.) (2012). Virus taxonomy: classification and nomenclature of viruses. Ninth report of the International Committee on Taxonomy of Viruses. 1327 p. https://books.google.com.ua/

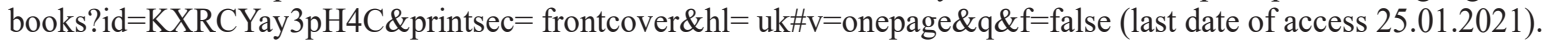

19. Vos, P.De, Garrity G.M., Jones, D., Krieg, N.R., Ludwig, W., Rainey, F.A., Schleifer, K.-H., Whitman, W.B. (2009). Bergey's manual of Systematic Bacteriology. 2nd ed. Vol. 3. The Firmicutes. 1422 p.

DOI https://doi.org/10.51647/kelm.2020.5.4.16

WEKTORY RUCHU W SEMIOSFERZE LIRYCZNEJ FABULY OLEKSANDRY PETROVOI

\author{
Svitlana Fokina \\ kandydat nauk filologicznych, \\ docent Katedry Literaturoznawstwa Ogólnego i Słowiańskiego, \\ doktorant \\ Odeskiego Narodowego Uniwersytetu imienia I.I. Miecznikowa (Odessa, Ukraina) \\ ORCID ID: 0000-0002-2406-0978 \\ svetlana_fokina@ukr.net
}

\begin{abstract}
Adnotacja. W artykule przedstawiono zrozumienie semiosfery ruchu jako sposobu na opanowanie włoskiej przestrzeni w poetyckim świecie O. Petrovoi. Celem tego artykułu jest określenie autorskich kodów oznaczających lejtmotyw ruchu i ścieżki na podstawie materiału wiersza O. Petrovoi „, Noc tu i tam. Mgła. Światła ciężarówek...”. Wybrana metodologia przedstawia kompleksową interakcję podejść i strategii analizy. Takie podejście badawcze przyczyniło się do ujawnienia potencjału semantycznego tekstu poetyckiego O. Petrovoi zgodnie z semiotycznym pryzmatem systemu figuratywnego i intencjami mitu autorskiego. Podczas analizy zidentyfikowano wzorce określające semiosferę lirycznej fabuły wiersza O. Petrovoi. Transgresywny status lirycznego ,ja”, na równi z wyznaczonymi kierunkami drogi, pozwolił wydobyć w nim potencjał tricksterski i zakwalifikować jako bohaterkę drogi. Twórcze przesłanie O. Petrovoi charakteryzuje się wysokim stopniem intertekstualności, co przyczynia się do rozszerzenia zakresu znaczeń zaktualizowanych w tekście. Istnieją odniesienia do dziedzictwa wybitnych poetów, którzy przeżyli wygnanie w jakiejś formie i są zgodne z O. Petrovą w zakresie cech postrzegania świata.
\end{abstract}

Słowa kluczowe: wektory ruchu, transgresja, semiosfera, palenie, bohater drogi, metamorfoza.

\title{
MOTION VECTORS IN THE SEMIOSPHERE OF THE LYRICAL PLOT OF ALEXANDRA PETROVA
}

\author{
Svitlana Fokina \\ Candidate of Philological Sciences, \\ Associate Professor at the Department of General and Slavic Literature, \\ Doctoral Candidate \\ Odessa I. I. Mechnikov National University (Odessa, Ukraine) \\ ORCID ID: 0000-0002-2406-0978 \\ svetlana_fokina@ukr.net
}

\begin{abstract}
The article presents an understanding of the semiosphere of movement as a way of developing Italian space in the poetic world of A. Petrova. The purpose of this article is based on the material of A. Petrova's poem "Night here and there. Fog. Truck lights..." identify author codes marking the leitmotif of movement and track. The chosen methodology represents the integrated interaction of analysis approaches and strategies. Such a research approach contributed to the disclosure of the semantic potential of the poetic text of A. Petrova in accordance with the semiotic prism of the figurative system and the intentions of the author's myth. During the analysis patterns were revealed that
\end{abstract}


determine the semiosphere of the lyrical plot of the poem by A. Petrova. The transgressive status of the lyrical "I" made it possible along with the indicated directions of the path, to identify the trickster potential in it and qualify it as the heroine of the road. Creative design by A. Petrova is distinguished by a high degree of intertextuality, which contributes to the expansion of the range of meanings updated in the text. References were noted to the legacy of prominent poets who survived expulsion in one form or another and are consonant with A. Petrova's features of the world perception.

Key words: motion vectors, transgression, semiosphere, smoking, road hero, metamorphoses.

\title{
ВЕКТОРЫ ДВИЖЕНИЯ В СЕМИОСФЕРЕ ЛИРИЧЕСКОГО СЮЖЕТА АЛЕКСАНДРЫ ПЕТРОВОЙ
}

\author{
Светлана Фокина \\ кандидат филологических наук, \\ доцент кафедры общего и славянского литературоведения, \\ докторант \\ Одесского национального университета имени И. И. Мечникова (Одесса, Украина) \\ ORCID ID: 0000-0002-2406-0978 \\ svetlana_fokina@ukr.net
}

\begin{abstract}
Аннотация. В статье представлено осмысление семиосферы движения как способа освоения итальянского пространства в поэтическом мире А. Петровой. Цель данной статьи на материале стихотворения А. Петровой «Ночь здесь и там. Туман. Огни грузовиков...» выявить авторские коды, маркирующие лейтмотив движения и пути. Избранная методология представляет комплексное взаимодействие подходов и стратегий анализа. Такой исследовательский подход способствовал раскрытию смыслового потенциала поэтического текста А. Петровой в соответствии с семиотической призмой образной системы и интенциями авторского мифа. В ходе анализа были выявлены закономерности, определяющие семиосферу лирического сюжета стихотворения А. Петровой. Трансгрессивный статус лирического «я», наравне с обозначенными направлениями пути, позволил выявить в нем трикстерский потенциал и квалифицировать как героиню дороги. Творческий посыл А. Петровой отличает высокая степень интертекстуальности, способствующая расширению круга актуализированных в тексте смыслов. Отмечены отсылки к наследию выдающихся поэтов, переживших в той или иной форме изгнание и созвучных А. Петровой особенностями мировосприятия.
\end{abstract}

Ключевые слова: векторы движения, трансгрессия, семиосфера, курение, герой дороги, метаморфозы.

Введение. Изученность творчества Александры Петровой в контексте поэтических экспериментов современного поколения поэтов-эмигрантов представляет открытый процесс и требует детальной разработки. Осмысление феномена самобытной поэтической манеры А. Петровой на данном этапе представлено в критике. Наиболее показательны изыскания С. Сандлер (Сандлер, 2008) и Г. Ермошиной (Ермошина, 2001), которые осмысляют закономерности творческого процесса А. Петровой, в частности тенденцию доминирования мотивов движения в книгах стихов «Вид на жительство» и «Только деревья». В предшествующем исследовательском опыте автора данной статьи были осуществлены попытки прочтения феномена ностальгии и «психейного сюжета» в третьей книге стихов А. Петровой «Только деревья». В рамках вышеупомянутых исследовательских практик были выявлены некоторые тенденции авторского мифа А. Петровой как поэта-эмигранта. Для интерпретации самобытности поэтического мира «Только деревьев» была предложена концепция, что для А. Петровой «страсть и самопознание не возможны без изгнания» (Фокина, 2019: 165) и включенности в онерическое пространство. Не менее значимым фактором стало выявление другой закономерности, связанной с развитием в лирике А. Петровой «психейного сюжета», который «актуализируя мифологический потенциал, включает в свой смысловой спектр мифологемы зарождения эроса» (Фокина, 2020: 42). Осмысление семиосферы движения как способа освоения итальянского пространства в поэтическом мире А. Петровой представляется продуктивной проблемой, требующей исследовательского внимания.

Основная часть. Цель статьи - на материале стихотворения А. Петровой «Ночь здесь и там. Туман. Огни грузовиков...» выявить авторские коды, маркирующие лейтмотив движения и пути.

В соответствии с заявленной целью определены следующие задачи: 1) осмыслить специфику представленных в тексте векторов движения; 2) рассмотреть лирическое «я» как героиню дороги; 3) выявить скрытый игровой адресат стихотворения.

Логика исследования мотивирована методологией, способствующей разностороннему прочтению стихотворения и раскрытию следующих ключевых категорий: движение, переходная эпоха, трансгрессия, идентичность, герой дороги, трикстер, метаморфозы, итальянский текст, курение. В ходе исследования с опорой на соответствующие концепции ученых были осмыслены: феномен переходности (М. Тростников, Н. Хренов, Ж. Старобинский), мифологичекие коды движения и семиосфера пути (Ю. Лотман, М. Элиаде, Т. Щепанская), специфика изгнания и ностальгии (С. Бойм, М. Гаспаров), семиотика курения (И. Богданов, К. Богданов, К. Леви-Стросс, Д. Марлан), трикстерский потенциал героев дороги (Ю. Лотман, Ж. Старобинский, Н. Тамарченко). Подобное комплексное взаимодействие подходов и стратегий анализа способствовало раскрытию смыслового потенциала поэтического текста А. Петровой в соответствии с семиотической призмой образной системы и интенциями авторского мифа. 


\section{Результаты.}

\section{1. Смыслопорождающие векторы движения в поэтическом тексте А. Петровой}

Для поэтики книги стихов «Только деревья» показателен фактор движения как освоения итальянского топоса. Согласно верному замечанию С. Сандлер, поэзия А. Петровой «вечно в движении, едва ли не более неустанном, чем в прежних книгах. Кажется, поэт только и делает, что идет, перемещается, - но и мир, по которому он перемещается, подвижен и зыбок...» (Сандлер, 2008: 6). Для А. Петровой путь предстает образом жизни, способом постижения подлинности бытия в сегодняшней подвижной, даже протеической реальности, становящейся формой обретения себя и познания мира. Такая изменчивость соответствует как ощущению непредсказуемости современности и отвечающим духу времени трансформациям, так и психосфере автора. По наблюдения Н. Хренова, «переходная эпоха < .. > соотносится скорее с дорогой, нежели с домом» (Хренов, 2002: 283). Не менее значим фактор потенциальной трансгрессивности авторского сознания А. Петровой как поэта-эмигранта. Перемещения в пространстве адекватны реальной биографии А. Петровой - переезд из Петербурга для учебы в Тарту, в дальнейшем эмиграция в Иерусалим, а позже в Рим. Для авторского мифа показателен образ мира, соответствующего метафоре «всё разбрелось теперь» из стихотворения «Пастух вещей», открывающего «Только деревья». В лирическом дискурсе А. Петровой различные векторы движения и семиотика дороги - индикаторы авторских кодов и глубинных смыслов.

Стихотворение А. Петровой «Ночь здесь и там. Туман. Огни грузовиков...» показательно взаимосвязью мотивов курения и движения, представленных как экзистенциалы лирического «я»:

Ночь здесь и там. Туман. Огни грузовиков

прочерчены зажжённой сигаретой.

Кури, кури, моя звезда,

поджёгшая меня ушедшим летом.

Неаполь, Рим, Венеция, Триест,

гони во весь опор, в один присест,

мчи под дождём во все железные лопатки,

читая вскользь дорожные щииты

в их фосфорной и лунной подзарядке.

Не беглець, не пленники, а так,

в луче тропь летим без изели,

что новый вид машинотел

на первозданной карусели.

\section{И если в звёздной пыли на стекле}

ты различишь жар прошльх превращчений,

то влажный след и блики на скуле,

быть может, будущеего тени (Петрова, 2008: 30).

Избранное для анализа стихотворение эксплицирует авторскую интерпретацию двух важных для А. Петровой векторов движения: воображаемого, связанного с курением и направлением струйки дыма, и вполне реального, осуществляемого как путешествие лирического «я» по итальянским городам. По словам Г. Ермошиной, «естественное состояние для Александры Петровой - путь. <...> Это не путешествие, это - способ существования» (Ермошина, 2001). Так путь воображения подразумевает самоуглубление, процесс творчества и погружение в ностальгию. Перемещение с юга на север Италии показательно авторской трансформацией традиционных мифологем. Путешествие лирического «я» реализует победу пассионарного начала над ностальгированием, устремленность к познанию нового места жительства и меняющегося мира. Переходность в лирическом сюжете А. Петровой эксплицируется на символическом уровне, обыгрывая разные аспекты пограничности: ночь, туман, сигаретный дым, дорога, карусель, «будущего тени». Ассоциативные сцепления представляют тему пути разнопланово: как воображаемое движение, как поездку-бег по автостраде и как полет по звездному небу. Взаимоотражение приземленного и возвышенного активизирует экспликацию не только бытового и бытийного, но и фантазийного, экзистенциального, ностальгического смысловых ракурсов.

\section{2. Трикстерские интенции в авторская модели итальянского текста}

Не менее примечательно географическое направление с юга на север и сам выбор итальянских городов - «Неаполь, Рим, Венеция Триест». Смена городов как разных ликов Италии и факторов познания лирическим «я» себя, своих чувств и окружающего мира, также представляет парадигму превращений, что подчеркивает автор в финале стихотворения («И если в звёздной пыли на стекле / ты различишь жар прошльхх превращений»). Для А. Петровой в целом показательно моделировать картину мира, зиждущуюся на смысловом взаимоотражении прошлого и настоящего, причем как личного, так и исторических, культурных и архетипических пластов.

Намеченная траектория пути, затрагивающая всю Италию, прочерчивает особенности культуры и мировосприятия каждого региона. Для лирического сюжета А. Петрова избирает путь не к центру и не закольцованное движение, а напротив - направление с юга на север. М. Элиаде отмечает, что «Центр есть область в высшей степени священного, область абсолютной реальности» (Элиаде, 2000: 35) и таково направление того, «кто ищет путь к себе» (Элиаде, 2000: 35). Выбор современным поэтом-эмигрантом принципиально 
иного направления, чем мифологическая модель, акцентирует авторский взгляд на мир как карту. В лирическом дискурсе А. Петровой проявляется ощущение лишенности корней и тайная тоска по ним (неслучайно деревья - знаковый образ третьей книги стихов). С точки зрения Т. Щепанской, «место в значительной мере определяет и идентичность.. <..> ... пребывание в пути, путешествие, становится знаком и условием принадлежности» (Щепанская, 2003: 42). Неоднозначность мировосприятия и возможность избежать лирическим «я» А. Петровой окончательной идентификации в соответствии с определяющей ролью локуса, высвечивает трикстерский потенциал. Трансгрессивность позиции А. Петровой как поэта-эмигранта вполне соотвествует тому, что трикстер «смещает привычные контуры реальности и создает сдвиги в ее понимании» (Тамарченко, 2007: 731). При подобном семиотическом ракурсе каждый из городов предстает самобытным, будучи при этом лишь остановкой в пути, сменяемой другим участком дороги, подобно идентификационным стратегиям эмигранта.

Показательно, что современный поэт-эмигрант изображает путь лирического «я» сродни переездам дальнобойщиков или путешествию автостопом. По мысли Ю. Лотмана, «действие, включенное в линейное временное движение, строилось, как повествование о постепенном одряхлении мира (старении бога)...» (Лотман, 2004: 284). Такая смысловая нагрузка не противоречит семантической парадигме книги стихов «Только деревья», посвященной римскому периоду жизни А. Петровой и не избегающей помимо поэтизированных и потенциально архетипических римских и шире итальянских реалий внимания к явлениям социального низа и эсхатологичности современного взгляда на мир.

Ракурс лирического «я» А. Петровой как героини дороги соответствует трикстерскому статусу и стремлению неизменно находиться «в движении и, что еще важнее, постоянно» пересекать «границы запретных пространств» (Лотман, 2004: 311). Тема пути вводится образом «зажженной сигареты», из огонька которой возникает визия и предчувствие путешествия через всю Италию, ставшую домом для поэта-эмигранта А. Петровой. В лирическом сюжете А. Петровой обыгрывается различные аспекты этого движения: его траектория, интенсивность, неизвестность окончательного пункта, наличие попутчика, непроясненность статуса лирического «я», обретение путеводной звезды.

\section{3. Идентификация курения как фантазийного перемещения в пространстве}

Мотив курения, включенный в поэтический текст в качестве одной из его доминант и травестирующий эмблематическую для русской культуры цитату «Гори, гори, моя звезда», несомненно, имеет знаковый характер. В данной связи вспоминается афоризм И. Бродского, приведенный в воспоминаниях друзей. Так Т. Венцлова в интервью отмечал: «Проблемой Бродского было курение. Он курил очень много, гораздо больше, чем надо.. < . .> Я как-то сказал Иосифу: “... не советую тебе курить. Брось!” На что он мне ответил замечательной фразой: “Обезьяна взяла в руки камень и стала человеком, человек взял в руки сигарету и стал поэтом”» (Венцлова, 2007). Тон высказывания И. Бродского совмещает ироничность и поэтичность, что в целом было присуще бродсковскому дискурсу. Аналогичная особенность определяет ход лирической эмоции у А. Петровой: от иронизации к возрастающей лиризации и философскому подтексту.

А. Петрова в качестве трансформируемого текста выбирает белогвардейский романс «Гори, гори, моя звезда», задавая самоидентификацию как эмигранта, но включенного в иные обстоятельства в экзистенциальном и мировоззренческом смыслах. А. Петрова не избегает иронии, но главным свойством обыгрывания цитаты романса становится не только эмблематичность и эффект авторского пародирования, но и переосмысление, способствующее зарождению лирического сюжета.

Дым предстает индикатором перехода в несколько измененное состояние сознания, будь то мечты, размышления, эмансипация личности, выход за пределы и даже магические практики. С эмблематической точки зрения призрачность, как один из доминантных кодов зажженной сигареты, способствует активации определенной цепочки значений. Возможны ситуации, когда «курение овеществляет пустоту, определяя внутреннее пространство тела (и внутренний мир) как пространство, заполняемое дымом» (Марлан, 2012: 346). В случае стихотворения А. Петровой реализуется принципиально другая семантическая наполненность акта курения, вполне могущего подразумевать курения фимиама, что синонимично поэтическому воспеванию. В данном контексте показательно свидетельство К. Леви-Стросса, что в некоторых вариантах мифологической системы Латинской Америки «табак превращается из обыкновенной магической субстанции в ипостась божества» (Леви-Стросс, 2000: 20). Так или иначе, именно курение в поэтическом тексте А. Петровой задает ощущение смысловой полноты иллюзорных образов, оживающих в воображении и перформативном слове поэта, символически предстающего курильщиком - участником некого языческого священнодейства, вполне соответствующего ностальгированию.

\section{4. Кармен - эмблематическая героиня табачной мифологии}

Мотив курения, заменяющий горение и в то же время сохраняющий смысловую цепочку, связанную с огнем и жаром, может акцентировать тему метаморфоз, колдовства, гадания о прошлом и будущем, а в подтексте и творчества. По наблюдениям К. Богданова, в западном мире «характерный пример знакового курения - демонстрация женской эмансипированности» (Богданов, 2015: 327-328). Более того, при совмещении противоречивых нарративов, курение фиксирует символику свободы. Такой семиотический аспект, связанный с «зажженной сигаретой» актуализирует значимые подтексты в стихотворении А. Петровой.

Культурный контекст курения представляет сигареты атрибутом Кармен, воплощающей страстность. Как известно, «героиня новеллы П. Мериме и оперы Ж. Бизе, работала на севильской табачной фабрике, где "papelitos" изготавливали вручную» (Богданов, 2007: 17). Для А. Петровой в книге стихов «Только 
деревья» важен образ цыгана, видимо, наследованный от русской культуры как знак творческой свободы, а главное подразумевающий судьбу эмигранта. По замечанию С. Сандлер, «... неспроста на страницах книги часто появляется цыган: с этим образом традиционно связан мотив кочевой жизни, в которой никакое место не ощущается как свое, как родной дом. <..> у Петровой <..> ее цыгане куда более настоящие, чем известные романтические образцы Мериме или Цветаевой» (Сандлер, 2008: 11). Обращая внимание на предложенное С. Сандлер столь концептуальное размежевание осмысления цыганских мотивов классиками XIX и XX веков с поисками современного поэта-эмигранта, стоит предположить и возможность альтернативного взгляда на данную проблему. Таким ракурсом представляется попытка выявления скрытого присутствия Кармен в анализируемом стихотворении А. Петровой, включающем также и память о лирических воплощениях роковой цыганки в интерпретации некоторых поэтов Серебряного века, в частности - упомянутой М. Цветаевой и А. Блока, создавшего наиболее последовательный миф о русской Карменсите.

В самых различных и порой даже взаимоисключающих интерпретациях Карменсита предстает неизменным воплощением рокового начала, причем как для своих избранников, так и для себя. Оперная ипостась Кармен высвечивает некую театральность и даже мистериальность лирического сюжета связанного с ней, метафорически обыгрывающего путь души. В восприятии фантазией спектакля как искушения, по наблюдению Ж. Старобинского, «...канатную плясунью легко сменит театральная актриса или певица» (Старобинский, 2002: 526), причем, такая женщина неизменно «обладает величайшим потенциалом метаморфоз, связанным с ее гибкостью...» (Старобинский, 2002: 527). Образ femme fatale по своей специфике не лишен не только амбивалентности в целом, но и непосредственно андрогинности, что во многом сближает его с цирковой, магической, даже трикстерской, протеической природой.

Как кантробандистка Кармен предстает героиней дороги, в этом плане становясь своего рода близнецом лирического «я» А. Петровой. М. Тростников акцентировал своеобразие семиотической рецепции Кармен в культуре. Онеричность, разные лики свободы и призрачность рая, «причудливо переплетаясь, противопоставляясь друг другу, так и самим себе, в результате сливаются в едином образе $<$...> - образе Кармен» (Тростников, 2006: 676). Такой ракурс взгляда на Карменситу открывает помимо поливалентности, заданной множеством трактовок, еще один важный аспект. Фатальная героиня символически воплощает ностальгию. В стихотворении А. Петровой на уровне подтекста Кармен предстает путеводной звездой и вместе с тем искусительницей, увлекающей в путь, который оказывается самоцелью существования. Ностальгия же настигает эмигранта, становясь его искушением, спутницей, отрадой и призмой взгляда на мир. Персонификация ностальгии в образе роковой женщины, при этом не лишенной трикстерских черт, вполне отвечает духу метаморфоз, который в своем тексте акцентирует А. Петрова как важную составляющую проходимого пути в обретении себя в новом месте жительства - итальянском мире.

\section{5. Жанровый потенциал лирического послания}

Стихотворение «Ночь здесь и там. Туман. Огни грузовиков...» можно декодировать в читательском восприятии и как любовное послание, чему не противоречит обращение «моя звезда». При таком прочтении текста возникает излюбленная А. Петровой неоднозначность: размывается гендерная идентификация и не ясно стихотворение написано от лица женщины или же мужчины. Для А. Петровой характерны подобные эксперименты с гендерной идентификацией, что проявляется в виде авторской редакции близнечного мифа о брате и сестре, ощущающих взаимное притяжение, и подменяющих друг друга в текстах «Только деревьев». Также до конца непрояснено, кто именно явлен объектом страсти и коммуникантом лирического «я», который поэтически назван «моя звезда». Данный адресат принципиально может иметь кодовые стратегии идентификации. Видимо, для А. Петровой важно моделировать ситуацию неоднозначности, побуждающую читательское восприятие подыскивать самые различные ипостаси вышеназванного обращения и так пытаться приблизиться к некой тайне.

Объект восхищения, к которому лирическое «я» в стихотворении А. Петровой обращается с практически заклинательной формулой: «Кури, кури, моя звезда», в авторской мифологии с помощью экстатичного чувства наделяется статусом своего рода божества или музы. С точки зрения С. Бойм, «тоска о товарище по ностальгии, а вовсе не тяга к родному ландшафту» создает необходимую почву для виртуального романа «между двумя “внутренними иммигрантами”, ощущающими себя изгнанниками на родной земле» (Бойм, 2019: 53). Подобный контекст обретения символического родства, даже близнечности присущ авторскому мифу А. Петровой. Помимо обыгрываемого в книге стихов «Только деревья» образа брата-близнеца, показательна заданность адресата или же автообращенности стихотворений, что позволяет прочитывать каждый поэтический текст данного периода как своеобразное лирическое послание.

\section{6. М. Цветаева как скрытый адресат}

Одним из предполагаемых адресатов может быть выдающийся поэт-эмигрант М. Цветаева - вдохновительница и своего рода путеводная звезда для лирического «я». Значимость поэтического наследия М. Цветаевой для А. Петровой несомненна. Свою книгу стихов, посвященную итальянским и римским реалиям нового места жительства, А. Петрова назвала «Только деревья», в чем явно прочитывается не только отсылка к знаменитому цветаевскому циклу «Деревья», но своего рода скрытое посвящение одному из любимых поэтов-предшественников. Как известно М. Цветаева была запойным курильщиком, и что еще более важно, включила подобное самовосприятие в свою лирику. Достаточно вспомнить ранние, но ставшие хрестоматийными строки: «В вечном дыме моей папиросы», из стихотворения 1913 года «Вы, идущие мимо меня...». Поэтизированный образ курящей и в определенном смысле андрогинной женщины, воплощает в семиосфере лирического сюжета А. Петровой силу поэтического дара и накал страстей. 
Тема сгорания и творческого горения также задает перекличку с наследием М. Цветаевой, отсылая к стихотворению «Что другим не нужно - несите мне...». Следующие цветаевские тематические блоки из вышеупомянутого поэтического текста: «Всё должно сгореть на моём огне!» и «Высоко несу свой высокий сан - / Собеседнииь и Наследницыь!» формируют своего рода подстрочник стихотворения А. Петровой. Так на уровне подтекста отыгрывается авторское стремление быть со своей стороны достойной «собеседницей и наследницей», приближаясь не только к мощному цветаевскому дарованию и накалу страстей, но и находясь в диалоге с мировой культурой, в первую очередь русской и итальянской.

Тема звезды, «поджёгшей», также заставляет вспомнить «горячие звезды» из лирики М. Цветаевой («Что горячи - над головою - звезды ...»). В цветаевском поэтическом дискурсе достаточно упоминаний звезд как воплощения не только совершенного, божественного и недостижимого, но и неизменно призывного, вдохновляющего и соответствующего жару души. М. Цветаева не только поэт-эмигрант, что созвучно жизненным реалиям самой А. Петровой, но и певец движения, бега, перемещения в пространстве, что было проявлено в цветаевском творчестве столь ярко и последовательно как, ни у одного представителя Серебряного века. Цветаевская траектория движения в лирике явно близка А. Петровой и носит для последней знаковый характер, задавая различные важные переклички с цветаевским творческим и даже в некоторой степени ментальным наследим. В то же время цветаевским кодом в подтексте стихотворения А. Петровой представляется соотношение сигареты со значениями свободы и пассионарности, в частности самой М. Цветаевой, как и излюбленной героиней цветаевской лирики - Кармен.

\section{7. Мотив метаморфоз в контексте авторского мифа А. Петровой}

В контексте эмигрантской самоидентификации лирического «я» А. Петровой вспоминаются Овидиевские исповедальные стихи о своей обездоленности вдали от Рима и от этого лишенности путеводной звезды. Ж. Старобинский, осмысляя овидиевское прощание с Римом в «Скорбных элегиях», характеризует эсхатологичность эмоциональной сферы древнеримского поэта-изгананника, отмечая интенсивность ностальгии, сопоставимой «с чем-то гораздо большим, нежели чувство потерянности на чужбине» (Старобинский, 2016: 275). Исследователь акцентирует овидиевское ощущение без-звездности, резюмируя, что «этимологически desiderium, скорее всего, отсылает к sidus, то есть звезда» (Старобинский, 2016: 274). Показательна связь тем путеводной звезды и божественного благословения, а также ощущение утраты данной перспективы ностальгиком. Овидий стал первым поэтом, воспевающим свое изгнание и скорбящим о покинутом мире в данном случае, Риме. Отсылка к овидиевскому эмиграционному опыту открывает связь темы путеводной звезды с мотивами метаморфоз, определяющими меняющиеся статус и самоощущение потенциально трансгрессивного сознания, которое вполне может быть соотносимо с феноменом поэта-эмигранта.

Так как авторская адресация «моя звезда» принципиально не прояснена и даже поливалентна, можно предположить и своеобразное автообращение. В соответствии с замыслом книги стихов «Только деревья» братом-близнецом лирического «я» предстает сам «растрепанный сборник» (Ср. «Кто узнает в лицо тебя, милый близнец...»). При такой авторской установке строки «Кури, кури, моя звезда» могут прочитываться как обращение сборника к своему автору - женщине-поэту. Строки «поджёгшая меня ушедшим летом» могут декодироваться как возникновение замысла и предчувствие осуществления будущей книги стихов, и как сожженния черновика, реализовав тем самым булгаковский завет, что «рукописи не горят». Тема сжигания знаковая как для русской литературы, так и для древнеримской.

Так Овидий, готовясь к предстоящей ссылке в Томы, сжигает свою знаменитую поэму «Метаморфозы». М. Гаспаров отмечает, что из-за опалы и предстоящей ссылки «Овидий считал себя погибшим. Он пытался покончить с собой - его с трудом удержали друзья. Он в отчаянии бросил в огонь почти законченные «Метаморфозы» < ..>, и поэму удалось потом восстановить лишь по спискам, оставшимся у друзей» (Гаспаров, 1995: 450). Сгорание написанного и возрождение к новой жизни - мотивы анализируемого стихотворения А. Петровой, обыгрывают идею превращений и трансформаций - центральную тему овидиевских «Метаморфоз».

Психотип поэта-эмигранта культурологически ориентирован на овидиевский опыт изгнанничества и последующую ностальгию. В данном плане А. Петрова скорее следует традиции, чем разрушает данную тенденцию. При этом каждый лирический сюжет книги стихов «Только деревья», не исключая анализируемое стихотворение, представляется своего рода серией метаморфоз, в этом повторяя интенции знаменитой поэмы Овидия. В поэтическом мире А. Петровой не избегают метаморфоз и трансформаций ни лирическое «я», ни окружающая реальность Рима и шире всей Италии, проявлением чего становятся и векторы движения.

Выводы. В ходе анализа были выявлены закономерности, определяющие семиосферу лирического сюжета стихотворения А. Петровой «Ночь здесь и там. Туман. Огни грузовиков...». К таким доминантам следует отнести представленные в тексте векторы движения. Путешествие по территории Италии способствует познанию мира нового места жительства и ощущению перемещений как экзистенциалов, определяющих своеобразие личности автора. Курение в соответствии с семиотическими кодами реализует движущую силу воображения и ностальгии. Персонификацией процессов курения и ностальгирования становится образ роковой Кармен. Трансгрессивный статус лирического «я», наравне с обозначенными направлениями пути, позволяет выявить в нем трикстерский потенциал и квалифицировать как героиню дороги. Творческий замысел А. Петровой отличает высокая степень интертекстуальности, способствующей расширению круга актуализированных в тексте смыслов. Значимы отсылки к наследию выдающихся поэтов, переживших в той или иной форме изгнание и созвучных А. Петровой особенностями мировосприятия. В частности анализируемый поэтический текст содержит аллюзии творчества и жизненного опыта Овидия и Марины 
Цветаевой. Вышеотмеченные образы эмигрантов-предшественников, включаются А. Петровой в семиосферу лирического сюжета как варианты своеобразия пути, трансгрессивности сознания, возможности самопознания лирического «я».

\section{Список использованных источников:}

1. Богданов И. Дым отечества, или Краткая история табакокурения. Москва: НЛО, 2007. 280 с.

2. Богданов К. А. Повседневность и мифология. Санкт-Петербург: Азбука, Азбука-Аттикус, 2015. 416 с.

3. Бойм С. Будущее ностальгии. Москва: НЛО, 2019. 680 с.

4. Венцлова Т. Бродский много и серьезно думал о смерти: [интервью]. Культура. $2007 . \quad$ № 2. URL: http://noblit.ru/node/1336

5. Гаспаров М. Л. Овидий в изгнании. Избранныле статьи. Москва: НЛО, 1995. С. 440-471.

6. Ермошина Г. Внутри чужого наречья. Знамя. 2001. № 5. URL: https://magazines.gorky.media/znamia/2001/5/ aleksandra-petrova-vid-na-zhitelstvo.html

7. Леви-Стросс К. Мифологики: в 4 т. Т. 2.: От мёда к пеплу. Москва; Санкт-Петербург: Университетская книга, 2000. $442 \mathrm{c}$.

8. Лотман Ю. М. Внутри мыслящих миров. Семиосфера. Санкт-Петербург: Искусство - СПБ, 2004. С. $150-390$.

9. Марлан Д. Эмблемы пустоты: курение как образ жизни в фильме Жана Эсташа «Мамочка и шлюха». Smoke. Bceмирная история курения. Москва: НЛО, 2012. С. 341-353.

10. Петрова А. Только деревья. Третья книга стихов. Москва: НЛО, 2008. 62 с.

11. Сандлер С. Поэт как перемещенное лицо: предисловие. Только деревья. Москва: НЛО, 2008. С. 5-12.

12. Старобинский Ж. Портрет художника в образе паяца. Поэзия и знание: История литературы и культуры: в 2 т. Т. 2. Москва: Языки славянской культуры, 2002. С. 501-581.

13. Старобинский Ж. Чернила меланхолии. Москва: НЛО, 2016. 616 с.

14. Тамарченко Н. Д. Трикстер. Культурология. Энцииклопедия: в 2 т. Т. 2 / [глав. ред. С. Я. Левит]. Москва: РОССПЭН, 2007. C. 730-734.

15. Тростников М. От Декаданса к Авангарду - поэтологический очерк европейского менталитета XX в. Семиотика и Авангард: Антология / [под общ. ред. Ю. С. Степанова]. Москва: Академический Проект; Культура, 2006. C. $675-692$.

16. Фокина С. А. Ностальгия в авторском мифе поэта-эмигранта Александры Петровой. Вчені записки таврійського національного університету імені В. І. Вернадського. Сер.: Філологія. Соціальні комунікації. 2019. Т. 30 (69). № 4. C. 161-166. DOI https://doi.org/10.32838/2663-6069/2019.4-1/30

17. Фокина С. А. Интерпретация «психейного сюжета» в эротическом дискурсе Александры Петровой. Південний архів. Сер.: Філологічні науки. 2020. Вип. LXXXII. C. 40-44. DOI https://doi.org/10.32999/ksu2663-2691/2020-82-6

18. Хренов Н. А. Культура в эпоху социального хаоса. Москва: Едиториал УРСС, 2002. 448 с.

19. Щепанская Т. Б. Молодежные сообщества. Современный городской фольклор / [отв. ред. С. Ю. Неклюдов]. Москва: РГГУ, 2003. С. 34-85.

20. Элиаде М. Миф о вечном возвращении. Избранные сочинения. Миф о вечном возвращении. Образы и символьл. Священное и мирское. Москва: Ладомир, 2000. С. 21-124.

\section{References:}

1. Bogdanov, I. (2007). Dym otechestva, ili Kratkaja istorija tabakokurenija [Smoke of the fatherland, or A brief history of tobacco smoking]. Moscow: NLO. [in Russian].

2. Bogdanov, K. A. (2015). Povsednevnost' i mifologija [Everyday life and mythology]. St. Petersburg: Azbuka, AzbukaAttikus. [in Russian].

3. Bojm, S. (2019). Budushhee nostal'gii [The future of nostalgia]. Moscow: NLO. [in Russian].

4. Ermoshina, G. (2001). Vnutri chuzhogo narech'ja [Inside alien dialect]. Znamja. Issue 5. URL: https://magazines.gorky. media/znamia/2001/5/aleksandra-petrova-vid-na-zhitelstvo.html

5. Fokina, S. A. (2019). Nostal'gija v avtorskom mife pojeta-jemigranta Aleksandry Petrovoj [Nostalgia in the author's myth of the emigrant poet Alexandra Petrova]. Vcheni zapiski tavrijs 'kogo nacional'nogo universitetu imeni V. I. Vernads'kogo. Ser.: "Filologija. Social'ni komunikaciï", vol. 30 (69), issue 4, pp. 161-166. DOI https://doi.org/10.32838/2663-6069/201 9.4-1/30 [in Russian].

6. Fokina, S. A. (2020). Interpretacija «psihejnogo sjuzheta» v jeroticheskom diskurse Aleksandry Petrovoj [Interpretation of the "mental plot" in the erotic discourse of Alexandra Petrova]. Pivdennij arhiv. Ser.: "Filologichni nauki", issue LXXXII, pp. 40-44. DOI https://doi.org/10.32999/ksu2663-2691/2020-82-6 [in Russian].

7. Gasparov, M. L. (1995). Ovidij v izgnanii. Izbrannye stat'i [Ovid in exile. Selected articles]. Moscow: NLO. pp. $440-471$. [in Russian].

8. Hrenov, N. A. (2002). Kul'tura v jepohu social'nogo haosa [Culture in the era of social chaos]. Moscow: Editorial URSS. [in Russian].

9. Jeliade, M. (2000). Mif o vechnom vozvrashhenii [Myth on eternal return]. Izbrannye sochinenija. Mif o vechnom vozvrashhenii. Obrazy i simvoly. Svjashhennoe i mirskoe. Moscow: Ladomir. pp. 21-124. [in Russian].

10. Levi-Stross, K. (2000). Mifologiki: v 4 t. T. 2.: Ot mjoda k peplu [Mythology: in 4 volumes vol. 2.: Horse of honey to ash]. Moscow; St. Petersburg: Universitetskaja kniga. [in Russian].

11. Lotman, Ju. M. (2004). Vnutri mysljashhih mirov. Semiosfera [Inside thinking worlds. Semiosphere]. St. Petersburg: Iskusstvo - SPB. pp. 150-390. [in Russian]. 
12. Marlan, D. (2012). Jemblemy pustoty: kurenie kak obraz zhizni v fil'me Zhana Jestasha «Mamochka i shljuha» [Emblems of Emblems: smoking as a lifestyle in Jean Eustache's film "Mommy and the Whore"]. Smoke. Vsemirnaja istorija kurenija. Moscow: NLO. pp. 341-353. [in Russian].

13. Petrova, A. (2007). Tol'ko derev'ja [Only trees]. Moscow: NLO. [in Russian].

14. Sandler, S. (2008). Pojet kak peremeshhennoe lico: predislovie [Poet as a displaced person: preface]. Tol'ko derev'ja. Moscow: NLO. pp. 5-12. [in Russian].

15. Shhepanskaja, T. B. (2003). Molodezhnye soobshhestva. Sovremennyj gorodskoj fol'klor [Youth communities. Modern urban folklore]. Moscow: RGGU. pp. 34-85. [in Russian].

16. Starobinskij, Zh. (2002). Portret hudozhnika v obraze pajaca [Portrait of the artist in the image of a jester]. Pojezija i znanie: Istorija literatury i kul'tury: v 2 t. T. 2. Moscow: Jazyki slavjanskoj kul'tury. pp. 501-581. [in Russian].

17. Starobinskij, Zh. (2016). Chernila melanholii [Ink of melancholy]. Moscow: NLO. [in Russian].

18. Tamarchenko, N. D. (2007). Trikster [Trickster]. Kul'turologija. Jenciklopedija: v 2 t. T. 2. Moscow: ROSSPJeN. pp. 730-734. [in Russian].

19. Trostnikov, M. (2006). Ot Dekadansa k Avangardu - pojetologicheskij ocherk evropejskogo mentaliteta XX v. [From Decadence to Vanguard: a poetic essay on the European mentality of the XX century]. Semiotika i Avangard: Antologija. Moscow: Akademicheskij Proekt; Kul'tura. pp. 675-692. [in Russian].

20. Venclova, T. (2007). Brodskij mnogo i ser'ezno dumal o smerti: interv'ju [Brodsky thought a lot and seriously about death: interview]. Kul'tura. issue 2. URL: http://noblit.ru/node/1336 